\title{
Cryptococcus agrionensis sp. nov., a basidiomycetous yeast of the acidic rock drainage ecoclade, isolated from an acidic aquatic environment of volcanic origin
}

Correspondence
Gabriel Russo
grusso@crub.uncoma.edu.ar

\author{
Gabriel Russo, ${ }^{1}$ Diego Libkind, ${ }^{1}$ Ricardo J. Ulloa, ${ }^{1}$ Virginia de García, ${ }^{1}$ \\ Jose P. Sampaio ${ }^{2}$ and María R. van Broock ${ }^{1}$
${ }^{1}$ Instituto de Investigaciones en Biodiversidad y Medioambiente (INIBIOMA-CONICET), Laboratorio de Microbiología Aplicada y Biotecnología, Centro Regional Universitario Bariloche, Universidad Nacional del Comahue (UNCo), Bariloche, Argentina \\ ${ }^{2}$ Centro de Recursos Microbiológicos, Departamento de Ciências da Vida, Faculdade de Ciências e \\ Tecnologia, Universidade Nova de Lisboa, 2829-516 Caparica, Portugal
}

The basidiomycetous yeasts of the genus Cryptococcus Vuillemin form a polyphyletic group comprising nearly 50 species, which are distributed in the orders Tremellales, Trichosporonales, Filobasidiales and Cystofilobasidiales of the subphylum Agaricomycotina (Fell et al., 2000; Bauer et al., 2006; Golubev et al., 2006). Species of the genus Cryptococcus have been isolated from a wide range of habitats, including extreme acidic aquatic environments, namely Rio Tinto (Spain), São Domingos mines (Portugal) and River Agrio-Lake Caviahue (RAC; Argentina). These environments are characterized by very low $\mathrm{pH}$ and high concentrations of heavy metals (López-Archilla et al., 2004; Gadanho et al., 2006; Russo et al., 2008).

The RAC is an acidic aquatic environment created by volcanic activity (Fehn et al., 2002). Its $\mathrm{pH}$ ranges from 1.5 at the source of the upper River Agrio (URA) to 6.4 at the lower River Agrio (LRA), $20 \mathrm{~km}$ downstream of the

Abbreviations: ARD, acid rock drainage; LRA, lower River Agrio; MSPPCR, mini/microsatellite-primed PCR; RAC, River Agrio-Lake Caviahue; URA, upper River Agrio.

The GenBank/EMBL/DDBJ accession numbers for the 16S rRNA gene sequences of Cryptococcus agrionensis sp. nov. CRUB $1317^{\top}$ and CRUB 1364 are EU627786 and EU627788, respectively.
Caviahue Lake (Russo et al., 2008). In 2004, conductivity ranged from $17.86 \mathrm{mS} \mathrm{cm}^{-1}$ (URA) to $0.24 \mathrm{mS} \mathrm{cm}^{-1}$ (LRA) (Russo et al., 2008). Concentrations of metals such as $\mathrm{Fe}, \mathrm{Mg}, \mathrm{Mn}, \mathrm{Al}$ and $\mathrm{Zn}$ were much higher at the source of the URA than at the LRA ( $\mathrm{mg} \mathrm{l}^{-1}: 2650.0$ to $6.0 ; 1930.0$ to $10.8 ; 79.8$ to $0.1 ; 921.0$ to 2.2 ; and 7.7 to lower than measurable levels, respectively) (Gammons et al., 2005).

During a study aimed at characterizing the biodiversity of the yeast community in the RAC aquatic system, 71 strains of an undescribed species of the genus Cryptococcus were isolated from six sampling sites along a section (approximately $30 \mathrm{~km}$ ) of the RAC system. A detailed description of each sampling site has been presented previously by Russo et al. (2008). All strains showed a remarkable ability to survive in the extremely acidic waters (Russo et al., 2008) suggesting that they are autochthonous to this environment. Phylogenetic analyses based on the D1/D2 region of the 26S rRNA gene showed that Cryptococcus ibericus was the most closely related species. Interestingly, strains isolated from the RAC were included in a clade composed of C. ibericus, Cryptococcus aciditolerans and Cryptococcus metallitolerans, which were isolated from acid rock drainage (ARD) of the São Domingos pyrite mine in Portugal (Gadanho \& Sampaio, 
2009). In this report, a novel species, Cryptococcus agrionensis sp. nov., of the order Filobasidiales, a putative autochthonous yeast of acidic environments, is described.

Novel strains were isolated from the RAC $\left(37^{\circ} 52^{\prime} \mathrm{S}\right.$ $\left.71^{\circ} 02^{\prime} \mathrm{W}\right)$ in March 2004. Yeast isolations were performed using solid MYP medium $(0.7 \%$ malt extract, $0.05 \%$ yeast extract, $0.25 \%$ peptone-soytone, $2.0 \%$ agar) and acidified (containing $2.5 \mathrm{M} \mathrm{H} \mathrm{H}_{2} \mathrm{SO}_{4}$ ) solid MYP medium (Russo et al., 2008). Conventional physiological and biochemical tests were performed according to Yarrow (1998). For determination of sexual compatibility, pairs of 2- to 4-day-old cultures were crossed on GSA medium $(0.2 \%$ glucose, $0.2 \%$ peptone-soytone, $1.5 \%$ agar $)$, incubated at room temperature for 2 weeks and examined for production of sexual structures.

For DNA extraction, protocols described by Sampaio et al. (2001) and Libkind et al. (2003) were employed. The mini/ microsatellite primed-PCR fingerprinting technique (MSPPCR) was used according to Libkind et al. (2003). The minisatellite primer M13 (5'-GAGGGTGGCGGTTCT-3') and the synthetic microsatellite oligonucleotide (GTG) were used to obtain species-specific DNA fingerprints (Sampaio et al., 2001). For sequence analysis, DNA was amplified using rRNA primers ITS5 and LR6. Cycle sequencing of the D1/D2 region at the $5^{\prime}$ end of the $26 \mathrm{~S}$ rRNA gene was performed according to Libkind et al. (2003). Sequences obtained were compared with those included in GenBank using BLAST (http://www.ncbi.nlm. nih.gov/). Sequence alignment was performed with MEGA 4 (Tamura et al., 2007) and adjusted visually. Phylogenetic and molecular evolutionary analyses were conducted using MEGA 4 with the neighbour-joining method (Saitou \& Nei, 1987). Bootstrap analyses were based on 1000 random resamplings.

C. agrionensis sp. nov. was the most abundant yeast found in the acidic waters of the RAC volcanic environment and was present at all sampling sites with $\mathrm{pH}$ values ranging from 1.8 to 6.7 (Russo et al., 2008). However, $97 \%$ of the isolates were obtained from the most acidic sampling sites (URA and Lake Caviahue, pH 1.8-2.7). All colonies were creamy white after the first few days of incubation at 20$22{ }^{\circ} \mathrm{C}$ in MYP agar, although after a week at $4{ }^{\circ} \mathrm{C}$ they became pale pink. Assimilation of myo-inositol and Dglucuronate as carbon sources, the capacity to hydrolyse urea and the inability to synthesize starch-like compounds indicated that the strains belonged to the genus Cryptococcus Vuillemin (Fell \& Statzell-Tallman, 1998). Mating assays were always negative as reproductive structures or cell-to-cell conjugation followed by formation of mycelium were not observed, indicating that the species was anamorphic.

MSP-PCR studies of both M13 and (GTG) $)_{5}$ primers suggested that all 71 strains were conspecific (Fig. 1). M13 MSP-PCR profiles were less conserved than (GTG) profiles and showed some variability. Such polymorphisms

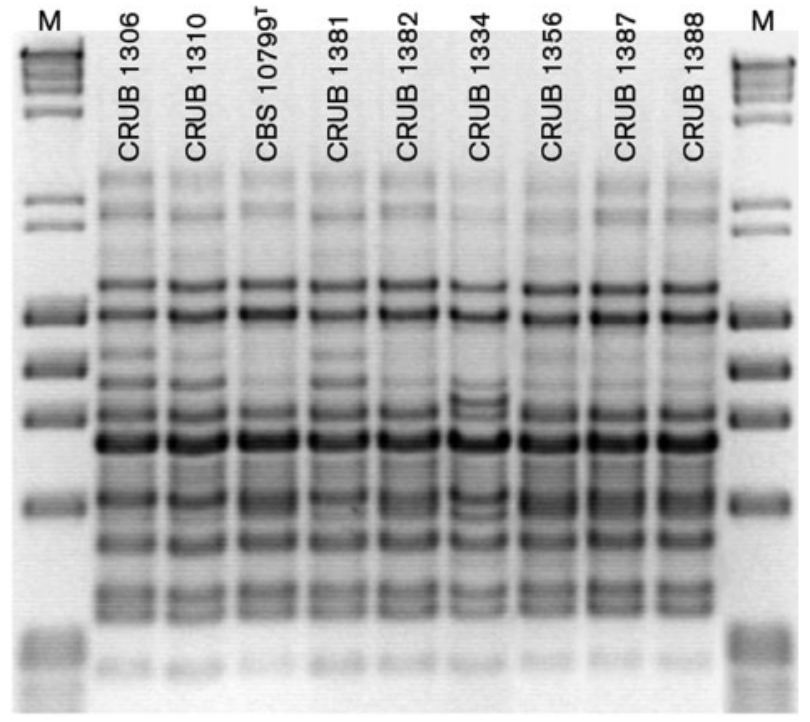

Fig. 1. MSP-PCR fingerprints of different isolates of $C$. agrionensis sp. nov. obtained with primer M13. Lane M, molecular marker.

among the novel isolates could not be related to any other ecological, physiological or molecular data. Sequence analysis of the D1/D2 region of six representative strains of C. agrionensis sp. nov. revealed no polymorphism ( $100 \%$ similarity). Phylogenetic studies showed that $C$. ibericus SDY $22^{\mathrm{T}}\left(=\mathrm{CBS} 10871^{\mathrm{T}}\right)$ was the most closely related strain to $C$. agrionensis sp. nov., although it is distantly related given that they differ in 35 nucleotides (Fig. 2).

Interestingly, phylogenetic analyses placed $C$. agrionensis sp. nov. in a separate clade composed of C. ibericus SDY $22^{\mathrm{T}}$, C. aciditolerans SDY $81^{\mathrm{T}}\left(=\mathrm{CBS} 10872^{\mathrm{T}}\right)$ and C. metallitolerans SDY $190^{\mathrm{T}}\left(=\mathrm{CBS} 10873^{\mathrm{T}}\right)$, isolated from ARD of São Domingos pyrite mine. Differences between the species isolated in São Domingos mine and $C$. agrionensis sp. nov. are shown in Table 1. Another interesting result is that $C$. agrionensis sp. nov., as observed with the three species from the São Domingos mine, proved to be highly resistant to heavy metals such as $\mathrm{Cd}^{2+}$, $\mathrm{Co}^{2+}, \mathrm{Cu}^{2+}, \mathrm{Li}^{+}, \mathrm{Ni}^{2+}$ and $\mathrm{Zn}^{2+}$ (unpublished data), further demonstrating the close relatedness of these species and their probable extremophile nature.

The clade composed of the three Cryptococcus species isolated from Portugal was designated the ARD ecoclade because of their isolation origin and distinctive ecology (Gadanho \& Sampaio, 2009). The term 'ecoclade' refers to species that are related phylogenetically and show salient physiological adaptations associated with the physicochemical conditions present in their habitats. However, the three Cryptococcus species constituting the ecoclade were isolated from the same geographical region and could have been claimed to be part of a geographical clade rather than an ecoclade. The present work provides evidence that 


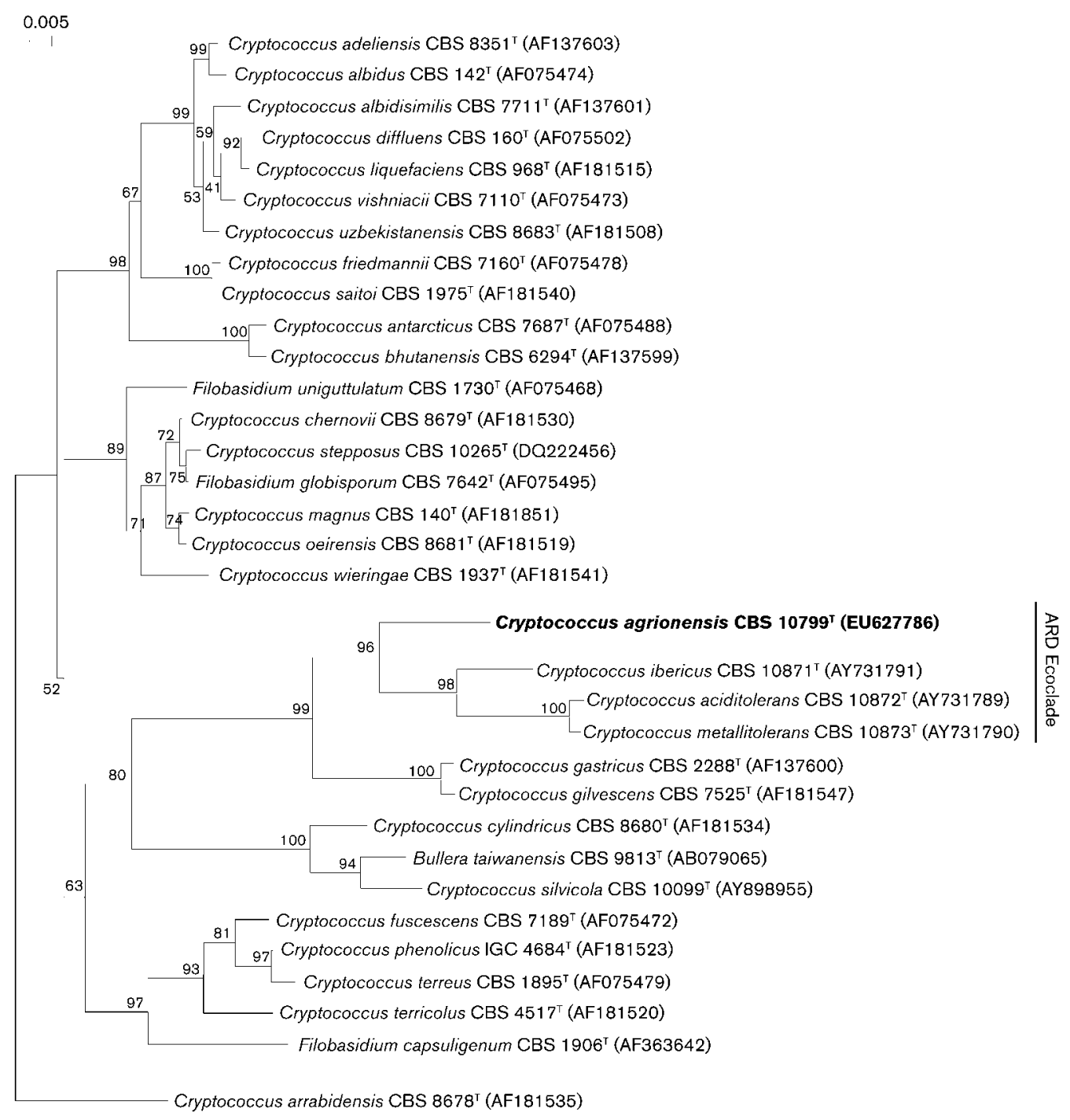

Fig. 2. Phylogenetic placement of $C$. agrionensis sp. nov. within the genus Cryptococcus inferred using the neighbour-joining method (distance Kimura two-parameter method) based on an alignment of nuclear DNA sequences from the D1/D2 region of the 26S rRNA gene. Cryptococcus arrabidensis was used as an outgroup. Number on the branches are bootstrap values (1000 replicates). GenBank accession numbers are given in parentheses. Branch lengths are in substitutions per site. Bar, 5 substitutions per site.

the ARD ecoclade is not restricted to the Iberian Pyrite region and demonstrates that members of this ecoclade may be found in acidic environments in general, originating both naturally and anthropically. These results further support the proposal of this phylogenetic group of yeasts as the ARD ecoclade.

\section{Latin diagnosis of Cryptococcus agrionensis Russo, Libkind, Sampaio et van Broock sp. nov.}

Fungus order Filobasidiales (Tremellomycetes, Agaricomycotina). In statu unicellulari cellulae ellipsoidae, 2$3 \times 5-8 \mu \mathrm{m}$. Mycelium verum non formatur. Glucosum non fermentatur. Substrata carbonica assimilate: amylum solubile (exigue), arbutinum, cellobiosum, citratum, D-arabinosum, DL-lactatum, galactosum, galactitolum (exigue), D-glucuronatum, glycerolum (exigue), D-glucono-1,5-lactonum, myoinositolum, erytritolum (lente), lactosum, L-arabinosum, Lrhamnosum, maltosum, D-mannitolum, melibiosum, melezitosum, raffinosum, ribitolum, D-ribosum, D-salicinum, sorbitolum, L-sorbosum, succinatum, trehalosum, D-xilosum et xilitolum (lente). Non assimilantur D-glucosaminum nec sucrosum. Substrata nitrogenica assimilate: nitritum, nitratum et cadaverinum; neque creatinum, creatininum, ethylaminum et L-lysinum. In media vitaminae externae non crescit. Non crescit 0.01 vel $0.1 \%$ cycloheximido addito. Materia amyloidea iodophila non formantur. Reactiones Diazonium caeruleum B et ureasii positivae. Crescit at $30{ }^{\circ} \mathrm{C}$, 
Table 1. Physiological and biochemical properties of $C$ agrionensis sp. nov., C. ibericus, C. aciditolerans and C. metallitolerans

Species: 1, C. agrionensis sp. nov.; 2, C. ibericus; 3, C. aciditolerans; 4, C. metallitolerans. Data are from this study and Gadanho \& Sampaio (2009). +, Growth; -, no growth; w, weak growth.

\begin{tabular}{|lcccc|}
\hline Characteristic & $\mathbf{1}$ & $\mathbf{2}$ & $\mathbf{3}$ & $\mathbf{4}$ \\
\hline Assimilation of carbon compounds: & & & & \\
D-Glucosamine & - & + & + & + \\
L-Rhamnose & + & + & - & - \\
Sucrose & - & + & + & + \\
Melezitose & + & + & + & - \\
Erythritol & W & + & + & + \\
L-Sorbose & + & - & - & + \\
D-Ribose & + & - & - & + \\
D-Arabinose & + & - & + & - \\
Ribitol & + & - & + & - \\
Galactitol & W & - & + & - \\
DL-Lactate & + & - & - & - \\
Assimilation of nitrogen compounds: & & & & \\
Potassium nitrate & + & - & - & - \\
Sodium nitrite & + & - & - & - \\
Cadaverine & + & - & - & - \\
Growth in/at: & & & & \\
Cycloheximide $(0.01 \%)$ & - & + & + & + \\
$35{ }^{\circ} \mathrm{C}$ & - & + & - & - \\
$37{ }^{\circ} \mathrm{C}$ & - & + & - & - \\
\hline
\end{tabular}

neque $35^{\circ} \mathrm{C}$ et $37{ }^{\circ} \mathrm{C}$. Sequentiae acidi nucleici partium D1/ D2 submonadis majoris ribosomalis typi in collectione sequentiarum acidi nucleici NCBI (www.ncbi.nlm.nih.gov) numeris EU627786 depositae sunt. Positio phylogenetica in Fig. 2 illustratur. Cultura typica numero $10799^{\mathrm{T}}$ in Centraalbureau voor Schimmelcultures (CBS), Ultrajecti, Hollandia, conservatur.

\section{Description of Cryptococcus agrionensis Russo, Libkind, Sampaio \& van Broock sp. nov.}

Cryptococcus agrionensis (a.gri.o.nen'sis. N.L. masc. adj. agrionensis of River Agrio, referring to the name of the river where most of the isolates were obtained).

Anamorphic yeast belonging to the subphylum Agaricomycotina, class Tremellomycetes, order Filobasidiales. Yeast cells after growth in MYP agar for 3 days at $20{ }^{\circ} \mathrm{C}$ are ellipsoidal $(2-3 \times 5-8 \mu \mathrm{m})$ and occur singly (Fig. 3$)$. Budding is polar. Pure cultures are white and smooth, with entire margins. After 1 week, colonies become pale pink at $4{ }^{\circ} \mathrm{C}$. All strains are positive for assimilation of the carbon compounds starch (weak), arbutin, cellobiose, citrate, D-arabinose, DL-lactate, galactose, galactitol (weak), D-glucuronate, glycerol (weak), D-glucono-1,5-lactone, myo-inositol, erythritol (delayed), lactose, L-arabinose, L-rhamnose, maltose, D-mannitol, melibiose, melezitose,

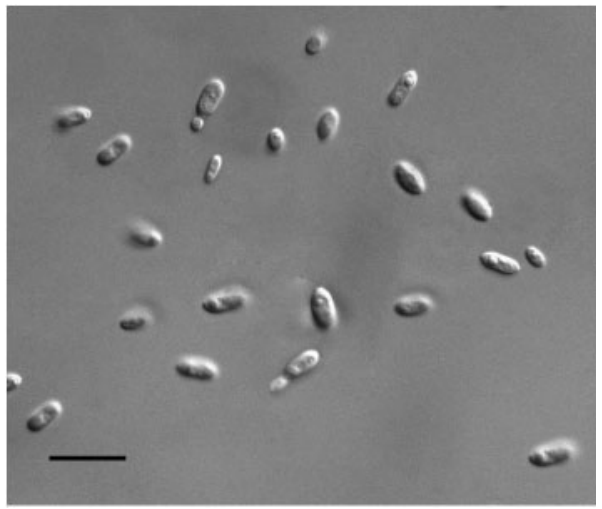

Fig. 3. C. agrionensis sp. nov. CBS $10799^{\top}$ vegetative cells after 3 days in MYP agar at $20^{\circ} \mathrm{C}$. Bar, $10 \mu \mathrm{m}$.

raffinose, ribitol, D-ribose, D-salicin, sorbitol, L-sorbose, succinate, trehalose, D-xylose and xylitol (delayed), and the nitrogen compounds cadaverine, potassium nitrate and sodium nitrite. All strains are positive for growth at $30{ }^{\circ} \mathrm{C}$. All strains are negative for fermentation of D-glucose, assimilation of the carbon compounds D-glucosamine and sucrose, and assimilation of the nitrogen compounds creatine, creatinine, ethylamine and L-lysine. All strains are negative for growth in vitamin-free medium, in $0.01 \%$ and $0.1 \%$ cycloheximide and at 35 and $37{ }^{\circ} \mathrm{C}$, and formation of starch-like compounds. Reaction with Diazonium Blue B and urease production are positive.

The type strain is CBS $10799^{\mathrm{T}}\left(=\mathrm{JCM} 15321^{\mathrm{T}}=\mathrm{CRUB}\right.$ $1317^{\mathrm{T}}$ ), isolated in 2004 from the RAC environment [subsurface water of the first sampling site of the upper River Agrio ( $\mathrm{pH} 1.8 ; 37^{\circ} 52^{\prime} \mathrm{S} 71^{\circ} 06^{\prime} \mathrm{W}$ )] by G. Russo. Strain CBS 10800 (=JCM 15322=CRUB 1364), isolated in 2004 from the RAC environment [subsurface water of the second sampling site of the upper River Agrio $(\mathrm{pH} 2.2$; $\left.37^{\circ} 53^{\prime} \mathrm{S} 71^{\circ} 04^{\prime} \mathrm{W}\right)$ ] by G. Russo, is a reference strain.

\section{Acknowledgements}

We thank the authorities of Parque Provincial Caviahue-Copahue (Argentina) for their courtesy and cooperation. This work was funded by the Universidad Nacional del Comahue (project B143), granted to M. R.v. B., and ANPCYT (project PICT 22200). Bilateral cooperation between Argentina and Portugal was supported by an SECYT-ICCTI cooperation agreement (PO/PA02-BI/002 and PO/07/017). G. R. was supported by a CONICET PhD fellowship. We would like to thank $\mathrm{Dr}$ C. Tognetti for her critical review of the manuscript, and Dr F. Pedrozo and Dr G. Baffico for providing data on the chemical composition of the RAC aquatic environment.

\section{References}

Bauer, R., Begerow, D., Sampaio, J. P., Weiß, M. \& Oberwinkler, F. (2006). The simple-septate basidiomycetes: a synopsis. Mycol Prog 5, $41-66$. 
Fehn, U., Snyder, G. T. \& Varekamp, J. C. (2002). Detection of recycled marine sediment components in crater lake fluids using ${ }^{129} \mathrm{I}$. $J$ Volcanol Geotherm Res 115, 451-460.

Fell, J. W. \& Statzell-Tallman, A. (1998). Cryptococcus Vuillemin. In The Yeasts, a Taxonomic Study, 4th edn, pp. 742-767. Edited by C. P. Kurtzman \& J. W. Fell. Amsterdam: Elsevier.

Fell, J. W., Boekhout, T., Fonseca, A., Scorzetti, G. \& StatzellTallman, A. (2000). Biodiversity and systematics of basidiomycetous yeasts as determined by large-subunit rDNA D1/D2 domain sequence analysis. Int J Syst Evol Microbiol 50, 1351-1371.

Gadanho, M. \& Sampaio, J. P. (2009). Cryptococcus ibericus sp. nov., Cryptococcus aciditolerans sp. nov. and Cryptococcus metallitolerans sp. nov., a new ecoclade of anamorphic basidiomycetous yeast species from an extreme environment associated with acid rock drainage in São Domingos pyrite mine, Portugal. Int J Syst Evol Microbiol 59, 2375-2379.

Gadanho, M., Libkind, D. \& Sampaio, J. P. (2006). Yeast diversity in the extreme acidic environments of the Iberian pyrite belt. Microb Ecol 52, 552-563.

Gammons, C. H., Wood, S. A., Pedrozo, F., Varekamp, J. C., Nelson, B. J., Shope, C. L. \& Baffico, G. (2005). Hydrogeochemistry and rare earth element behavior in a volcanically acidified watershed in Patagonia, Argentina. Chem Geol 222, 249-267.

Golubev, W. I., Sampaio, J. P., Alves, L. \& Golubeva, E. W. (2006). Cryptococcus silvicola nov. sp. from nature reserves of Russia and Portugal. Antonie van Leeuwenhoek 89, 45-51.
Libkind, D., Brizzio, S., Ruffini, A., Gadanho, M., van Broock, M. R. \& Sampaio, J. P. (2003). Molecular characterization of carotenogenic yeasts from aquatic environments in Patagonia, Argentina. Antonie van Leeuwenhoek 84, 313-322.

López-Archilla, A. I., González, A. E., Terrón, M. C. \& Amils, R. (2004). Ecological study of the fungal populations of the acidic Tinto River in southwestern Spain. Can J Microbiol 50, 923-934.

Russo, G., Libkind, D., Sampaio, J. P. \& van Broock, M. R. (2008). Yeast diversity in the acidic Rio Agrio-Lake Caviahue volcanic environment (Patagonia, Argentina). FEMS Microbiol Ecol 65, 415424.

Saitou, N. \& Nei, M. (1987). The neighbor-joining method: a new method for reconstructing phylogenetic trees. Mol Biol Evol 4, 406425.

Sampaio, J. P., Gadanho, M., Santos, S., Duarte, F. L., Pais, C., Fonseca, A. \& Fell, J. W. (2001). Polyphasic taxonomy of the basidiomycetous yeast genus Rhodosporidium: Rhodosporidium kratochvilovae and related anamorphic species. Int J Syst Evol Microbiol 51, 687-697.

Tamura, K., Dudley, J., Nei, M. \& Kumar, S. (2007). MEGA4: Molecular Evolutionary Genetics Analysis (MEGA) software version 4.0. Mol Biol Evol 24, 1596-1599.

Yarrow, D. (1998). Methods for the isolation, maintenance and identification of yeasts. In The Yeasts, a Taxonomic Study, 4th edn, pp. 77-100. Edited by C. P. Kurtzman \& J. W. Fell. Amsterdam: Elsevier. 